\title{
WAIVER OF THE RIGHT TO COUNSEL IN STATE COURT CASES: THE EFFECT OF GIDEON $V$. WAINWRIGHT
}

In Gideon $v$. Wainwright, ${ }^{1}$ the Supreme Court held that the denial of the appointment of counsel to an indigent defendant in a state court violates due process. ${ }^{2}$ Although Gideon may be read generally as extending to state defendants the same right to counsel now guaranteed to federal defendants under the sixth amendment, ${ }^{3}$ important questions concerning the exercise of the right still remain.* One of these questions, the subject of this comment, is whether the rigorous standards governing waiver of counsel in federal cases ${ }^{5}$ now apply in state proceedings. This is important, for an easy finding of waiver in the state courts may substantially undermine the right guaranteed in Gideon.

1372 U.S. 335 (1963).

2 Although this is the general holding, certain questions were left unanswered by the decision. See Israel, Gideon $v$. Wainwright, The "Art" of Overruling, 1963 SUP. Cr. REv. 211, $271 \mathrm{n} .337$. Included among these questions are whether the decision applies retroactively and whether or not the right to have counsel appointed applies to minor crimes, misdemeanors and nontrial situations. See Beaney, The Right To Counsel: Past, Present, and Future, 49 VA. L. REv. 1150, 1155 (1963); Kamisar, Betts $v$. Brady Twenty Years Later: The Right to Counsel and Due Process Values, 61 Mich. L. Rev. 219, 268-70 (1962). See also 15 ALA. L. REv. 568 (1963); 17 U. MIAMI L. Rev. 371 (1963); Comment, 30 TENN. L. Rev. 420 (1963). The recent Second Circuit opinion in Durocher v. Lavallee, 32 U.S.L. WEEK 2502 (2d Cir. Mar. 26, 1964), indicates that the Gideon decision will be read to apply retroactively.

3 The federal requirements were outlined generally in Johnson v. Zerbst, 304 U.S. 458 (1988). Until Gideon the right to appointment of counsel was constitutionally guaranteed to state court defendants only when there was a capital charge, Powell v. Alabama, 287 U.S. 45 (1932), or "special circumstances" such as youth or below average mentality, see Betts v. Brady, 316 U.S. 455 (1942). Before Gideon fourteen states did not appoint counsel in the absence of the capital charge or "special circumstances." McNeal v. Culver, 365 U.S. 109, 119-22 (1961) (appendix) (Douglas, J., concurring); Kamisar, The Right to Counsel and the Fourteenth Amendment: $A$ Dialogue on "The Most Pervasive Right" of an Accused, 30 U. CHI. L. REv. I, 17 n.76 (1962).

4 See note 2 supra.

5 In recognizing the right to appointment of counsel in federal prosecutions, the Court has linked the waiver standards to the basic right itself: "A waiver is ordinarily an intentional relinquishment or abandonment of a known right or privilege. The determination of whether there has been an intelligent waiver of the right to counsel must depend, in each case, upon the particular facts and circumstances which surround the case, including the background, experience, and conduct of the accused. . . . The purpose of the constitutional guarantee of a right to counsel is to protect an accused from conviction resulting from his own ignorance of his legal and constitutional rights, and the guaranty would be nullified by a determination that an accused's ignorant failure to claim his rights removes the protection of the Constitution." Johnson v. Zerbst, 304 U.S. 458, 464-65 (1938). See also Moore v. Michigan, 355 U.S. 155 (1957); United States v. Nickerson, 124 F. Supp. 35 (D. Mass. 1954). 
The recent Ohio case of Doughty v. Sacks, ${ }^{6}$ remanded by the Supreme Court for reconsideration in the light of Gideon, ${ }^{7}$ illustrates basic differences between state and federal waiver standards. The Ohio court held that regardless of the decision in Gideon, the petitioner had waived his right to counsel by pleading guilty without requesting appointment of counsel. There appeared to be no evidence that the petitioner had been informed of his right to counsel by the trial court, and the only indication that he knew of his right was a reference to an out of court discussion of the matter with his wife. ${ }^{8}$

6175 Ohio St. 46, 191 N.E.2d 727 (1963). Since this comment has gone to press the Supreme Court granted certiorari and reversed the Doughty decision in a two sentence per curiam opinion, Doughty v. Maxwell, 84 Sup. Ct. 702 (1964). In reversing, the Court cited Carnley v. Cochran, 369 U.S. 506 (1962), and Gideon v. Wainwright, 372 U.S. 335 (1963). In Durocher v. LaVallee, 32 U.S.L. WeEK 2502 (2d Gir. March 26, 1964), the court of appeals relied heavily upon the Supreme Court's per curiam reversal of Doughty in overturning pre-1959 state convictions where the defendants had pleaded guilty without requesting appointment of counsel. Judge Kaufman, writing for the majority, rejected any limitation of the Gideon decision to cases where the defendant had pleaded not guilty and commented on the impossibility of entering an intelligent plea to a criminal charge without the aid of counsel. He held that the rejection in Gideon of the "fundamental fairness" doctrine of Betts v. Brady, 316 U.S. 455 (1942), is equally applicable to cases where guilty pleas are entered, thus casting doubt upon Banks v. Maxwell, 195 N.E.2d 801 (Ohio 1964) (per curiam). See text accompanying note 50 infra. Judge Friendly, in a concurring opinion, felt that the result in Durocher did not automatically follow from Gideon, but was now required as a result of the Supreme Court's reversal in Doughty. Judge Friendly's reasoning that the result in Durocher did not follow directly from Gideon, indicates that other courts, not giving as much weight to the per curiam reversal of Doughty, may reach a different conclusion. This indicates that the problems posed by the Doughty case have more complex overtones than is admitted by the twenty-two word opinion of the Supreme Court.

7 The case was first decided in the Ohio court on the grounds that Doughty never requested legal assistance and that in pleading guilty he had waived his right to counsel. 173 Ohio St. 407, 183 N.E.2d 368 (1962). The United States Supreme Court remanded the case for reconsideration in the light of Gideon, sub nom. Doughty v. Maxwell, 372 U.S. 781 (1963). On the decision after remand the Ohio Supreme Court rested its dismissal of Doughty's petition on the sole ground that he had not requested counsel, mentioning for the first time the allegation that he had discussed the appointment of counsel with his wife.

8 Ohio was one of the states which nominally provided counsel for all indigent defendants prior to Gideon. See McNeal v. Culver, 365 U.S. 109, 119-22 (1961) (appendix) (Douglas, J., concurring). The Doughty case followed In re Burson, 152 Ohio St. 375,89 N.E.2d 651 (1949), which held a plea of guilty to be a valid waiver of the right to counsel. The defendant in Burson, because of a prior criminal record, was presumed to have knowledge of his rights. The court said that while "perhaps it was unfortunate that the trial court did not specifically advise the petitioner concerning his right to counsel ... under the circumstances with the [prior criminal] record of the petitioner before it, the court might assume that he knew his rights in this respect and chose to plead guilty rather than stand trial on a charge concerning which he knew he had no defense." Id. at 654. One can question the court's assumption that a defendant without legal training would know that there were no available to request counsel may be suspect even under Ohio law. In In re Motz, 100 Ohio App. defenses. The proposition in Doughty that waiver is presumed from the simple failure 
The waiver standards in Doughty clearly differ from those for federal prosecutions. In general, the federal waiver principle is that to be valid, a waiver must be a knowing and intelligent choice to proceed without the aid of counsel. ${ }^{9}$ Practically, this requirement means that the federal trial judge must determine by a careful colloquy with any uncounseled defendant whether he understands the charge, the consequences of the various pleas and the opportunity and availability of counsel. The judge must while doing this take into account the "background, experience and conduct of the accused."10

In contrast to the result in Doughty, the simple failure to request counsel would not be enough for a federal court to find a waiver of the right. Nor could a plea of guilty be the sole basis for such a finding. ${ }^{11}$

296, 136 N.E.2d 430 (1955), the defendant pleaded not guilty after her lawyer was permitted to withdraw from the case. The court held: "[O]bviously it cannot be claimed that the petitioner waived any right she had to the protection of the court in assigning counsel to defend her, whether requested by her or not." (emphasis added). But see Banks v. Maxwell, 195 N.E.2d 801 (Ohio 1964).

9 See, e.g., Walker v. Johnston, 312 U.S. 275 (1941); Johnson v. Zerbst, 304 U.S. 458 (1938); Cherrie v. United States, 179 F.2d 94 (10th Cir. 1949); United States v. Nickerson, 124 F. Supp. 35 (D. Mass. 1954).

10 "[A]s a minimum, the court, in order to discharge its duty, must advise the defendant of the seriousness of the charge, that the Constitution of the United States guarantees him the right to have the assistance of counsel for his defense, and that if he is unable to employ counsel, it is the duty of the court to appoint, and the court will appoint, counsel for him. Ordinarily, only by such an inquiry can the court be sure that the defendant understands his constitutional right and intelligently waives it." Cherrie v. United States, supra note 9, at 96. In Von Moltke v. Gillies, 332 U.S. 708, 720 (1948), an intelligent German-born woman accused of wartime espionage was deemed not to have waived her right to counsel: "The petitioner's case bristled with factors that made it all the more essential that, before accepting a waiver of her constitutional right to counsel, the court be satisfied that she fully comprehended her perilous situation ...." The procedures required in federal courts, judicially developed, have been codified in the Federal Rules of Criminal Procedure. See FED. R. CRIM. P. 44.

11 The requirement that any waiver must be knowing and intelligent logically precludes either a plea of guilty or a failure to request counsel from being enough for a finding of waiver. See United States v. Nickerson, 124 F. Supp. 35, 37 (D. Mass. 1954): "The United States argues that defendant, by his course of conduct in pleading guilty without requesting the assistance of counsel made an effective waiver of his right to counsel. While a waiver might be implied from such conduct in some circumstances, a waiver, to be effective, must be intelligently made. A defendant's failure to request counsel does not constitute a waiver if he does not know that he has a right to have counsel." See also Glasser v. United States, 315 U.S. 60 (1941); Wood v. United States, 128 F.2d 265 (D.C. Cir. 1942) (dictum). A federal court has apparently held that a person unable to understand his position will not be deemed to have waived his right even in the face of acts purporting to do so. United States v. Vargas, 124 F. Supp. 197 (D.P.R. 1954). That case involved an eighteen-year-old boy from very "humble" origins who spoke no English and with only an eighth grade education. The district court ruled that Vargas was not competent to waive counsel, although an interpreter was always present, raising the interesting possibility that some persons may be forced to be represented by counsel against their will. 
While a guilty plea may in some circumstances have probative value on the question of waiver, such a plea by itself would be insufficient in a federal court to support a finding that counsel had been waived.12

The suggestion in Doughty that the defendant's conversation with his wife concerning counsel creates a presumption that he knew of his right to have counsel appointed is inconsistent with federal standards. Federal courts are to indulge every reasonable presumption against waiver and are reluctant to infer that the defendant has knowledge of his right to have counsel appointed simply from his background or criminal record. ${ }^{13}$ This reluctance would most likely extend to such out of court conversations as the one in Doughty.

Other states, including Pennsylvania, West Virginia and Florida, appear to have rules of waiver directly at variance with federal practice.14 In Pennsylvania a plea of guilty, intelligently entered, acts as a waiver of the right to counsel ${ }^{15}$ and failure to request counsel, especially when the guilty plea is present, may be regarded as a waiver of the right.18 In West Virginia the courts have characterized a plea of guilty as a waiver even where the defendant lacked an average knowledge of the legal and factual questions in the case. ${ }^{17}$ In Florida, at least before Gideon, the right to counsel was held waived if not requested and waiver was presumed from the absence in the record of evidence to the contrary. ${ }^{18}$

12 United States v. Nickerson, supra note 11.

13 Id. at 37. See also Von Moltke v. Gillies, 332 U.S. 708 (1948). In Glasser v. United States, 315 U.S. $60(1941)$, the Court held that the fact that the petitioner was an attorney was not conclusive of knowledge of his rights. Compare Banks v. Maxwell, 195 N.E.2d 801 (Ohio 1964), where the Ohio court inferred knowledge of the right from a defendant's prior criminal record.

14 It is often difficult to determine precisely what the state waiver standards are. In those states that before Gideon did not appoint counsel in all cases, waiver was infrequently discussed. Some states seem to apply flexible standards of waiver, varying with the severity of the charges, apparently in an attempt to avoid reversal under the Betts rule. See, e.g., De Meerleer v. Michigan, 329 U.S. 663 (1947), reversing 313 Mich. 548, 21 N.W.2d 849 (1946); In re Elliott, 315 Mich. 662, 24 N.W.2d 528 (1946).

15 See Commonwealth ex rel. Harris v. Cavell, $195 \mathrm{~Pa}$. Super. 196, 171 A.2d 630 (1961); Commonwealth ex rel. Bruce v. Burke, 170 Pa. Super. 642, 90 A.2d 258 (1952).

16 See Commonwealth ex rel. Henderson v. Kruger, 180 Pa. Super. 374, 119 A.2d 870 (1956); Commonwealth ex rel. Ridenour v. McHugh, 179 Pa. Super. 69, 115 A.2d 808 (1955). Development of the Pennsylvania waiver rules is based in part upon the Betts doctrine, and the decision in Gideon may cause Pennsylvania to change its position. See Commonwealth ex rel. Simon v. Maroney, 405 Pa. 562, 176 A.2d 94 (1961).

17 Wade v. Skeen, 140 W. Va. 565, 85 S.E.2d 845 (1955). See also United States ex rel. Fitch v. Adams, 165 F. Supp. 22 (N.D.W. Va. I958); 65 W. VA. L. Rev. 297 (1963).

18 See Butier v. Culver, 111 So. 2d 35 (Fla. 1959); Sneed v. Mayo, 66 So. 2d 865 (Fla. 1953). Since the Gideon decision the Florida courts seem to have brought their procedures in line with the federal practice. Alford v. Wainwright, 156 So. 2d 1 (Fla. 1963); King v. State, I57 So. 2d 440 (Fla. 1963).

Illinois may have waiver rules which restrict the right to counsel guaranteed in 
The importance of the standards governing waiver of the right to have counsel appointed is shown by the fact that about sixty per cent of those accused of felonies in the United States are financially unable to retain counsel. ${ }^{19}$ Experience in the federal courts indicates that the number of waivers in this group is substantial, and that there appears to be a relationship between the number of waivers and the manner in which the courts apply the waiver standards. Despite the solicitous federal rules, the percentage of defendants who waive varies from a negligible number in some districts to the preponderance of defendants in others.20 "Disparity among districts apparently can be explained only by differences in attitude among district judges toward permitting a defendant to plead without counsel."21 If some states do not even meet

Gideon. A 1949 Illinois rule requires the appointment of counsel to all indigent defendants and requires the trial judge carefully to determine whether the defendant fully understands his situation and rights. Sup. Ct. Rule 26, Irr. REv. Stat. ch. 110, $\$ 101.26$ (1949). The effect of this requirement has been somewhat diminished by judicial interpretation. The Illinois Supreme Court has held that an instruction to an accused that, "If you want to plead not guilty you have the right to stand trial and I would appoint an attorney to represent you, but if you want to plead guilty there's no use to appoint an attorney to represent you," is adequate under the Illinois rule. People v. Flathers, 414 III. 486, 488, 111 N.E.2d 530, 531 (1953). The instruction would seem to imply that only if the defendant thought a plea of not guilty proper could he seek the appointment of counsel. Such an instruction would not be acceptable under the federal rules as it might lead a defendant to decide prematurely to plead guilty before he was aware of his true situation. Glasser v. United States, 315 U.S. 60 (1942); United States v. Vargas, 124 F. Supp. 195 (D.P.R. 1954). Moreover, despite the fact that the Illinois Constitution has a provision similar in wording to the United States Constitution with regard to the right of counsel, Il. Consr. art. II, $\S 9$, in People v. Pring, 414 Ill. 63, 69, 110 N.E.2d 214, 217 (1953), the Illinois Supreme Court commented that the "contention that he [petitioner] was deprived of a substantial constitutional right is based on the bald allegation that no counsel was appointed for him and he was not apprised of his right to counsel. Such an allegation does not state a deprivation of a substantial constitutional right." See also People v. Reese, 410 Ill. 11, 100 N.E.2d 907 (1951); People v. Brown, 12 Ill. App. 2d 476, 139 N.E.2d 809 (1956) (abstract only). Contra, Comment, 43 ILL. L. REv. 664 (1948). Possible procedural difficulties for a defendant convicted without benefit of counsel appear to have been closed by the new set of Illinois Supreme Court rules effective January 1, 1964, implementing the new Judicial Article of the Illinois Constitution. See Jenner, The Illinois Post-Conviction Hearing Act, SMrth-Hurd Ild. AnN. Stat. ch. 38, at 359 (Supp. 1963).

19 Report of the AtT'y Gen.'s CoMm. on POVERTY \& the AdMinistration of Federal Criminal Justice 16 (1963). See also Ass'n of the Bar of the Crty of New York \& Nat. Legal AId \& Defender Ass'N, EQual Justice for the Accused 39 (1959).

20 Report of the Atr'y Gen.'s CoMm. ON POVERTy \& the ADMinistration of Feneral Criminal Justice 128 (1963). The Sacramento division of the Northern District of California reported that about $67 \%$ of their defendants waived counsel during the year ending June 1, 1961, while the San Francisco division of the same district reported that only 1\% waived counsel. Ibid. Note, 76 HARv. L. REv. 579, 584 (1963), reports that "the percentage of defendants who waive the right to counsel varies greatly: in about half the districts, less than twenty per cent waive, but in a few districts more than eighty per cent may do so."

21 Note, 76 HARv. L. REv. 579, 584 (1963). There are other factors of course, such 
the minimum federal standards, one would expect to find that waivers in these states were even more common. ${ }^{22}$ In particular, if a plea of guilty should act as a waiver of the right to appointment of counsel then that right would be of little value in the majority of criminal prosecutions. In the federal courts about seventy per cent of those accused initially plead guilty ${ }^{23}$ and similar statistics obtain in the state courts. ${ }^{24}$

The holding in Gideon does not necessarily mean that federal waiver principles now apply in full detail to the states. Although the majority in Gideon defined the right extended by reference to the sixth amendment, they did not use the argument urged by Mr. Justice Douglas, in a concurring opinion, that the fourteenth amendment incorporates the specific provisions of the Bill of Rights, and thus provides the same protection in state and federal prosecutions. ${ }^{25}$ Avoidance of a "total incorporation" doctrine, however, is not inconsistent with the view that Gideon places additional restraints upon state waiver procedures. ${ }^{26}$

as the nature of the crimes and the "type" of defendants predominantly being tried, but these factors hardly account for the great disparity in the number waiving the right within the same federal district. See note 20 supra.

22 Comprehensive statistics for state courts appear to be almost nonexistent.

$2371.3 \%$ of the defendants in federal courts in 1962 initially plead guilty and $15.25 \%$ subsequently entered guilty pleas. Table II, attached to a Letter From the Administrative Office of the United States Courts to the Harvard Law Review, cited in Note, 76 HARv. L. REv. 579, 583 n.12 (1963).

24 In Connecticut in 1961-62, 1434 of the 1769 cases disposed involved pleas of guilty. 18 Judictal Councrl of Conn. Rep. 22 (1962). In December, 1963, 167 of the 320 cases in the Criminal Court of Cook County, Illinois, involved guilty pleas. OFFICE of The Deputy Court Administrator for CoOK County of the Illinois Supreme Court, Statistical Bull. 4 (Dec. 1963). In North Dakota, 232 of the 277 cases disposed of in the first half of 1962 were by guilty pleas. N.D. Court Administration, Compilation of the CleRks Reporx-Criminal (1963).

25 The Gideon decision is hardly conclusive on the issue of whether the due process clause incorporates the sixth amendment as such. The majority decision speaks of whether the constraint of the sixth amendment expressed a rule so fundamental to a fair trial that it was obligatory by the due process clause. The majority spoke in terms of making sections of the original Bill of Rights "obligatory on the States," and conceded that "Betts was wrong . . . in concluding that the Sixth Amendment's guarantee of counsel is not one of these fundamental rights." Gideon v. Wainwright, 372 U.S. 335, 342 (1963). Mr. Justice Douglas, concurring, thought that the Court should have applied the full force of the sixth amendment to the states, presumably including federal rules of waiver based on constitutional grounds. Id. at 345-47. For an interesting view of the "incorporation problem" generally, see Henkin, "Selective Incorporation" In the Fourteenth Amendment, 73 YALE L.J. 74 (1963).

26 Even if Gideon does apply the sixth amendment per se to the states, the courts must still determine which, if less than all, of the federal waiver standards are constitutionally required in order to fully exercise the right. When the state procedure questioned is one as basic as "inference of waiver from a plea of guilty," there may be little difference between determining what procedures are necessarily part of the sixth amendment right itself and what ones are required by fourteenth amendment due process. Difference may arise, however, when the question is one of a relatively "minor" rule of procedure. 
Since the constitutional right to have counsel appointed is now generally extended to the states, state waiver rules must certainly meet the "fundamental fairness" principle of the due process clause. ${ }^{27}$

Support for extension of federal waiver practices to the states as a requirement of due process is found in Supreme Court cases decided under the Betts $v$. Brady ${ }^{28}$ standard. Where "special circumstances" required the appointment of counsel in state cases, the Court applied as corollary to that right, basic federal waiver principles. ${ }^{29}$ In Herman $v$. Claudy, the Court held that

where a person convicted in a state court has not intelligently and understandingly waived the benefit of counsel and where the circumstances show that his rights could not have been protected without counsel, the Due Process Clause invalidates the conviction. ${ }^{30}$

2i A traditional test for the due process clause of the fourteenth amendment has been whether the procedure in question is a "denial of fundamental fairness shocking to the universal sense of justice." Betts v. Brady, 316 U.S. 455, 462 (1942). See also Lisenba v. California, 314 U.S. 219, 286 (1941); Palko v. Connecticut, 302 U.S. 319 (1937). Mr. Justice Harlan qualified his concurring opinion in Gideon by "not read[ing] our past decisions to suggest that by so holding, we automatically carry over an entire body of federal law and apply it in full sweep to the States. Any such concept would disregard the frequently wide disparity between the legitimate interests of the States and of the Federal Government, the divergent problems that they face, and the significantly different consequences of their actions.... I do not understand the Court ... to embrace the concept that the Fourteenth Amendment 'incorporates' the Sixth Amendment as such." Gideon v. Wainwright, 372 U.S. 335, 352 (1963).

Mr. Justice Harlan's position is in accord with the language used by the Court in Bute v. Illinois, 333 U.S. 640 (1948). In Bute, the petitioner claimed to have been deprived of his right to counsel under the Betts doctrine. This claim was ultimately rejected by the Court, but in a dictum the Court disposed of the claim that certain Illinois waiver procedures violated petitioner's constitutional rights. They said that the due process clause does not require the states to conform their criminal trial procedures to those used in the federal courts even though the procedures of the federal courts are prescribed by the Federal Constitution and the Bill of Rights. Id. at 650. See also Foster v. Illinois, 332 U.S. 134, 139 (1947); Twining v. New Jersey, 211 U.S. 78, 79 (1908). Carnley v. Cochran, 369 U.S. 506 (1962), seems clearly contradictory to the language in Bute and indeed avoids overruling the case by restricting it to its narrow holding that under the facts the "special circumstance" test of Betts was not satisfied.

28316 U.S. 455 (1942). For an interesting commentary on the manner in which Betts was overruled by Gideon, see Israel, supra note 2.

29 Such special circumstances included a capital charge, an ignorant or illiterate defendant, a complicated charge or other factors which made the prosecution more unfair than prosecutions normally are when defendants are uncounseled. See, e.g., Cash v. Culver, 358 U.S. 633 (1959); Betts v. Brady, 316 U.S. 455 (1942); Powell v. Alabama, 287 U.S. 45 (1932). This distinction has been criticized in Israel, supra note 2 , at 250 . Skilled representation may be as necessary in noncapital cases because these cases are often more complex. See Allen, The Supreme Court, Federalism, and State Criminal Justice, 8 DE PAUL L. REv. 213, 230-31 (1959).

30350 U.S. 116, 118 (1956). Here the Court held that a twenty-one-year-old defendant 
In addition to applying the basic federal waiver principle, the courts have frequently applied specific federal standards. The Supreme Court has disallowed an inference of waiver from a failure to request counsel, ${ }^{31}$ and has refused to countenance any presumption of waiver from a silent record. ${ }^{32}$ Finally, in 1962 the Court in Carnley v. Cochran ${ }^{33}$ held that the principles in Johnson $v$. Zerbst, ${ }^{34}$ the leading case on federal waiver requirements, were equally applicable in state court proceedings. ${ }^{35}$

Since the federal courts in cases arising under Betts have applied federal standards of waiver, it may be argued that the extension of the right to counsel in Gideon correspondingly extends the federal waiver structure to the states. This argument is not without difficulty. The waiver principles enunciated in Johnson v. Zerbst and apparently incorporated by Cochran are expressed in the most general terms. ${ }^{36}$ Nothing is said about which specific federal standards are to be applied to the states. It may, of course, be argued that at least those specific standards already applied in cases arising under Betts should now be similarly applied under Gideon. However, not all federal waiver rules have been stringently and uniformly applied against the states. For example, although

with only six years schooling and not informed of his right to counsel had not waived this right. This basic application of the federal waiver principle requiring an intelligent and understanding waiver is not, of course, the same as applying the full detail of the federal waiver rules or procedures. See also Carnley v. Cochran, 369 U.S. 506, 515 (1962).

31 "It is settled that where the assistance of counsel is a constitutional requisite, the right to be furnished counsel does not depend on a request." Carnley v. Cochran, supra note 30 , at 513. See also Uveges v. Pennsylvania, 335 U.S. 437 (1948); Rice v. Olson, 324 U.S. 786 (1945).

32 Johnson v. Zerbst, 304 U.S. 458, 464-65 (1938): “'[G]ourts [must] indulge every reasonable presumption against' waiver of fundamental constitutional rights and ... we "do not presume acquiescence in the loss of fundamental rights." "See also Carnley v. Cochran, 369 U.S. 506, 516 (1962). In Patton v. North Carolina, 315 F.2d 643 (4th Gir. 1963) (prior to Gideon), the court went so far as to say that it was clear that an effective waiver of counsel could not be implied.

33 Carnley v. Cochran, supra note 32.

34304 U.S. 458 (1938).

35369 U.S. at 515 (1962). Moore v. Michigan, 355 U.S. 155 (1957), also intimates the application of the totality of the federal waiver structure to the states: "Whatever may be the differences in the substantive right to counsel . ..., he [petitioner] should carry the same burden of proving nonwaiver as is required of a defendant in a federal case. We therefore hold that the rule of Johnson $v$. Zerbst applies in this case ...." Id. at 161 .

38 "The sixth amendment withholds from federal courts, in all criminal proceedings, the power and authority to deprive an accused of his life or liberty unless he has or waives the assistance of counsel. ... [W]aiver is ordinarily an intentional relinquishment or abandonment of a known right or privilege. ... [T] he guaranty [of the sixth amendment] would be nullified by a determination that an accused's ignorant failure to claim his rights removes the protection of the Constitution." Johnson v. Zerbst, 304 U.S. 458, 463-65 (1938). 
federal standards clearly forbid the inference of waiver from a plea of guilty alone, the courts ordinarily have allowed the states to infer such a waiver in lieu of evidence supporting a contrary intent. ${ }^{37}$

Even if all federal waiver standards were not applied against the states, the argument that they now should be is strengthened by analogy to Mapp v. Ohio. ${ }^{38}$ In Mapp the federal rule excluding illegally seized evidence was found to be constitutionally required in state courts. To do otherwise, the Court held, would make "the freedom from state invasions of privacy ... so ephemeral and so neatly severed from its conceptual nexus with the freedom from all brutish means of coercing evidence as not to merit this Court's high regard as a freedom 'implicit in the concept of ordered liberty." "39 By force of this argument, those federal waiver standards indispensible to an intelligent exercise of the right to counsel are to be required in state courts.

Ker $v$. California, ${ }^{40}$ decided in the same term as Gideon, lends additional support to the argument for extending the federal waiver standards to the states. In Ker, the Court faced the problem of applying Mapp to a state search apparently acceptable under California law but arguably illegal by federal standards. ${ }^{41}$ The Court held that the evidence

37 Although the language in Carnley seems to apply the federal presumptions against waiver to the states under the Betts series, specific results in the lower federal courts do not always reveal such an application. Thus a state court may "ordinarily" infer a waiver of counsel from a plea of guilty as compared with the federal rule disallowing such an inference. Compare Kennedy v. Burke, 176 F.2d 96 (3d Cir. 1949), and Fitch v. Adams, 165 F. Supp. 22 (N.D.W. Va. 1958), with cases cited in note 11 supra. To what extent this dichotomy will be resolved by Carnley remains to be seen. A guilty plea will not, however, constitute a waiver in a state court in the face of evidence to the contrary. "It is apparent that the court's [Nebraska] Supreme Court] affrmance did not rest on its statement that a plea of guilty "ordinarily implied' a waiver of the right to counsel, but upon a holding that such a plea 'absolutely' and finally waived that right. This is inconsistent with our interpretation of the fourteenth amendment." Rice v. Olson, 324 U.S. 786, 788 (1945). Compare Kennedy v. Burke, supra, a state prosecution in which the court found that a presumption of waiver from a plea of guilty did not violate due process inasmuch as the defendant was sufficiently mature and intelligent and had sufficient experience with the law to be aware of his right to counsel, with United States v. Nickerson, $124 \mathrm{~F}$. Supp. 35 (D. Mass. 1954), a federal prosecution in which the court discredited any implication of the defendant's knowledge of his rights based on his prior experience in the criminal process.

38367 U.S. 643 (1961).

39 Id. at 655 .

40374 U.S. 23 (1963).

41 There was little doubt in Mapp that the state search was illegal. Mapp v. Ohio, 367 U.S. 643, 645 (1961). The search in Ker involved an entry into a suspect's room to make an arrest. The California court concluded that the entry was for the purpose of making an arrest based upon probable cause and that hence the search incident to the arrest was legal. 195 Cal. App. 2d 246, 257, 15 Cal. Rpt'x 773, 782 (1962). A similar entry was held improper in a federal case in Miller v. United States, 357 
was admissible in the state court even if it might have been inadmissible in a federal prosecution. Ker thus applied less rigorous standards in enforcing the search and seizure protection in state courts. ${ }^{42}$ The Court's reasoning, however, was based on the fact that the federal standard in question was developed in cases in which the Court was exercizing only its supervisory power over federal procedure. ${ }^{43}$ The Court observed that the constitutional standard for what is an "unreasonable search" is the same for state and federal searches. Ker thus suggests that waiver standards based on constitutional grounds are applicable against the states under the fourteenth amendment.

It seems clear that the federal waiver standards are constitutionally based. Even with the codification of those standards in the Federal Rules of Criminal Procedure, 44 the Court has consistently indicated that they are not merely statutory, but based on requirements of the sixth amendment. ${ }^{45}$ Moreover, those federal waiver standards which have been ap-

U.S. 301 (1958), as violative of 18 U.S.C. $\S 3109$ (1958). "Insofar as . . a a federal statute required the exclusion of a federal search in Miller, the case is inapposite for state prosecutions, where admissibility is governed by constitutional standards. . . . We ... hold that in the particular circumstances of this case the ... entry was not unreasonable under the standard of the fourth amendment as applied to the States through the fourteenth amendment." 374 U.S. at 44.

42 The Court split eight to one in Ker on the proposition that the same standards of constitutional reasonableness for searches were to be applied for state and federal searches. Only Mr. Justice Harlan supported more flexible standards of fundamental fairness for judging the state cases. The eight split evenly on whether the search at issue would have been illegal under federal law due to constitutional grounds, or due only to statute or standards developed by the Court in its supervisory capacity over federal procedure. Thus, while five members of the Court agreed that different standards may apply to state than to federal searches, four of those five limited such variance to the cases in which more rigorous federal rules are not based on constitutional grounds. In his opinion Mr. Justice Harlan argued, "Heretofore ... federal searches and seizures have been subject to the requirement of 'reasonableness' contained in the Fourth Amendment. ... State searches and seizures, on the other hand, have been judged, and in my view rightly so, by the more flexible concept of 'fundamental fairness,' of rights 'basic to a free society' embraced in the Due Process Clause of the Fourteenth Amendment. . . . Today this distinction in constitutional principles is abandoned. Henceforth state searches and seizures are to be judged by the same standards as apply in the federal system. In my opinion this further extension of federal power over state criminal cases ... is quite uncalled for and unwise." 374 U.S. at $44-45$.

43 The distinction between constitutional grounds and the supervisory power of the Court over federal procedure is not a precise one. In Ker, even if the federal standards regarding searches were not held to be constitutionally required, it can hardly be doubted that they were designed to support the constitutional right. See note 42 supra. While the majority of eight in the decision agreed that the same standards of constitutionality would govern state and federal searches, this decision is dictum inasmuch as the California rule admitting the evidence was sustained.

44 Fed. R. Grim. P. 44.

45 The Court has said that it is, "to preserve the protection of the Bill of Rights 
plied to the states under Betts have been applied as constitutional requisites of the fourteenth amendment. ${ }^{46}$

Even if it can be argued that not all federal waiver rules are required in state courts, inferences of waiver from a plea of guilty or from failure to request counsel are inconsistent with the basic right itself. The apparent intent of Gideon is that counsel must be made available to indigent defendants at all important stages of the criminal proceeding. ${ }^{47}$ Certainly the entry of a plea is an act which itself requires counsel. The uncounseled defendant may be unaware of valid defenses or that his constitutional rights were violated by the police. Even when guilt is clear, it is important that the defendant be properly represented. At least onethird of those defendants with retained counsel in federal courts who initially plead not guilty later change their pleas to guilty, intimating that plea and sentence bargaining is common.48 Counsel would certainly be of help in such bargaining. 49

It is internally illogical to presume a waiver of the right to have counsel appointed from an act which can only be intelligently exercised with the aid of counsel. In an attempt to meet such an argument, the Ohio Supreme Court in Banks v. Maxwell" has resurrected the Betts "special circumstances doctrine." In Banks the defendant prisoner sued for a writ of habeas corpus claiming that he was unrepresented at trial and that counsel was not offered to him by the court. The court held, as it did in Doughty, that the defendant's uncounseled plea of guilty raised a presumption of waiver. The court went on to say that such a presumption can be drawn unless the lack of counsel on a guilty plea

for hard-pressed defendants [that] we indulge every reasonable presumption against the waiver of fundamental rights." Glasser v. United States, 315 U.S. 60, 70 (1942). See also Aetna Ins. Co. v. Kennedy, 301 U.S. 389 (1937).

46 Carnley v. Cochran, 369 U.S. 506 (1962).

47 The Court has recently ruled that a plea of guilty at a preliminary hearing entered without counsel is not admissible at trial, White v. Maryland, 373 U.S. 59 (1963) (per curiam). The Court has specifically required the appointment of counsel for appeals as of right, Douglas v. California, 372 U.S. 353 (1963).

48 Report of the ATt'y Gen.'s CoMm. ON POVERTY \& the ADMinistration of Federal. Criminal Justice (1963). The figures were obtained by dividing the number of final guilty pleas less initial pleas of guilty by the total number of not guilty pleas. There may be some, however, who change from guilty to not guilty which would increase the proportion. The ratios were San Francisco 75/215; Sacramento 10/32; Northern District of Illinois, 54/147; and District of Conn., 27/82. Obviously other factors than plea bargaining may lead an attorney to have his client plead guilty, but this process probably accounts for the greatest number, particularly among defendants represented by the professional criminal bar. See DonNELLY, GoLDSTEIN \& Schwartz, Criminal Law 48-52 (1962).

49 Most federal judges believe that counsel is also helpful in the sentencing procedure to insure that any mitigating factors are presented. Comment, 76 HARV. L. REv. 579, 585 (1963).

50 Banks v. Maxwell, 195 N.E.2d 801 (Ohio 1964) (per curiam). 
constitutes a denial of due process. ${ }^{51}$ Whether it does or does not is determined by the circumstances surrounding the plea-i.e., criminal record, mentality and youth. By this ploy the Betts case, rather than being overruled, is merely removed to a different plane. Banks overlooks the principal thrust of Gideon, that it is always an unfair proceeding if the right to appointment of counsel is denied.

The inference of a waiver from a failure to request counsel is also a non sequitur. It is the one who is most in need of counsel who is likely to be so unfamiliar with his rights as not to know how or when to ask for appointment of counsel.

In conclusion, it may frequently be proper for state criminal procedure to vary from federal practice. It may even be argued that the burden is initially on those who seek to displace state procedures with federal ones. ${ }^{52}$ But when minimum standards have been developed in federal cases to prevent the derogation of a right equally guaranteed to state defendants, the burden would seem to have been met and only a conflict with a substantial state interest should prevent their application to the states. But such interests are not obvious with regard to rules of waiver. Unlike $M a p p$, where over half the states had considered and rejected the exclusionary rule, ${ }^{53}$ only a few states apply waiver standards clearly in conflict with those applied in federal courts. If the greater care required by trial courts in ascertaining waiver actually results in a need for additional counsel for indigent defendants, then the inferences drawn from the less rigid standards are unjustified.

Both precedent ${ }^{54}$ and policy require the application of the federal waiver structure to the states. The price exacted is a few more minutes of the trial court's time-the gain, increased respect for state criminal procedures.

51 "In order for lack of counsel on a plea of guilty to constitute a denial of due process, it must appear that such lack of counsel so prejudiced the accused that he was unfairly confined, and that such lack was apt to result in injustice." Id. at 802.

52 See Henkin, supra note 25, at 77.

53 See Allen, Federalism and the Fourth Amendment: A Requiem For Wolf, 1961 Sup. Cr. REv. 1, 2.

54 The post Gideon cases on the waiver issue are few, but they indicate that federal waiver standards are being applied to the states in all criminal cases. A district court in Louisiana has interpreted Gideon to require the entire federal procedure of informing the defendant of his rights even in state court cases. Louisiana ex rel. Byrnes v. Walker, 217 F. Supp. 168 (E.D. La. 1963). In Post v. Boles, 218 F. Supp. 658 (N.D.W. Va. 1963), the court commented on the issue: "Counsel for petitioner maintains that since the Supreme Court's opinion in Gideon $v$. Wainwright, the same rules govern for determining the validity of a waiver of counsel whether the alleged waiver occurred in a federal court or in a state court. That may be a correct statement of the law, but the issue is academic in this case." Id. at 661 . See also United States ex rel. Noll v. Fay, 219 F. Supp. 262 (S.D.N.Y. 1963). For more recent case developments, see note 6 supra. 